\title{
PREVALENCE OF CELIAC DISEASE IN DYSPEPTIC PATIENTS
}

\author{
Vinícius Machado de LIMA ${ }^{1}$, Lenora GANDOLFI ${ }^{2}$, \\ José Augusto de Araújo PIRES ${ }^{1}$ and Riccardo PRATESI ${ }^{2}$
}

ABSTRACT - Background - Celiac disease is one of the most common dietary-mediated inflammatory enteropathies that occur in genetically predisposed individuals in response to gluten intolerance. This disorder has become more common than in the past, even if it frequently remains undetected for long periods of time. The screening of patients with dyspepsia, a symptom that can be a manifestation of celiac disease, may allow an early identification of affected individuals. Endoscopy and serological tests may have an important role in the management of these patients. Aims - Determining the prevalence of celiac disease in dyspeptic patients submitted to routine diagnostic upper gastrointestinal endoscopy. Patients/Methods - Endoscopic findings, duodenal biopsy histological specimens and serological test results were assessed and compared in 142 patients consecutively admitted with dyspeptic symptoms between October 2001 and October 2003. Results - An endoscopic pattern suggestive of celiac disease was observed in four patients. The IgG-AGA assay was positive in 24 patients. Two of the IgG-AGA positive patients also yielded positive results on the IgA-EMA test and concomitantly disclosed endoscopic pattern and histological features in duodenal biopsy compatible with celiac disease. Abnormal endoscopic findings were notably marked in biopsy proven celiac patients. Therefore, a $1.4 \%$ prevalence of celiac disease was observed in this study group. Conclusions - The high prevalence of celiac among dyspeptic symptomatic individuals indicates that they are a higher risk group for developing celiac disease. Undiagnosed celiac disease may be inferred by endoscopic markers of duodenal villous atrophy. Endoscopic findings, however, may be inadequate to suitably diagnose this disease and consequently the incorporation of diagnostic serologic assays of celiac disease in routine testing for dyspepsia is strongly recommended.

HEADINGS - Celiac disease. Dyspepsia. Prevalence.

\section{INTRODUCTION}

Celiac disease (CD), one of the most common dietarymediated inflammatory enteropathies, occurs in response to gluten intolerance. This dietary component, consisting of the proteic fraction found in wheat, barley and rye, is known to induce lesions of the small intestinal mucosa mediated by the immune system. In addition to gluten exposure, susceptible individuals also possess a genetic predisposition as an important determining factor in CD. In fact, genetically susceptible individuals are known to express specific human leukocyte antigen alleles (DQ2 and DQ8) ${ }^{(24,28)}$.

The actual prevalence of $\mathrm{CD}$ has been shown to be more frequent than in the past. Until recently CD was considered uncommon even in Europe, with a prevalence rate of about $1: 1000^{(14,21)}$. However, with the advent of serological tests for population screening, several European studies have shown that the true prevalence of CD may be 1:200 or even greater ${ }^{(5,6,19)}$. Similar figures were found in the USA, where NOT et al. ${ }^{(23)}$ reported a prevalence of 1:250 among healthy blood donors. In South America, CD has been traditionally considered a rare disorder and extensive investigations on its prevalence were practically nonexistent. However, several studies performed during the last few years in Brazil disclosed a prevalence varying between 1:681 in healthy blood donors ${ }^{(15)}$ and 1:473 among adult outpatients attending a clinical laboratory of a general hospital for routine blood testing ${ }^{(25)}$. In Argentina, GOMEZ et al. ${ }^{(16)}$ found, among normal couples attending a prenuptial obligatory examination, an even greater prevalence of 1:167. Therefore, it has become evident that a significant number of CD cases have gone by undetected in clinical diagnoses, generally those related to atypical symptoms. Alarmingly, for every confirmed case in Europe, seven are estimated to have remained undetected ${ }^{(6)}$. This diagnosed/undiagnosed ratio was shown to be even higher in Argentina (1:12) ${ }^{(16)}$. Such discrepancy may be attributed, in part, to the wide range of digestive and extradigestive clinical symptoms. In many cases, normally expected malabsorptive symptoms, including diarrhea or steatorrhea, weight loss, and abdominal distension may not necessarily be observed. Within this broad clinical spectrum, description of asymptomatic forms of $\mathrm{CD}$ has increased considerably ${ }^{(8)}$ and the presence of dyspepsia as a unique symptom has been frequently attributed to $\mathrm{CD}^{(3)}$.

Given that over $40 \%$ of the general population exhibits dyspeptic complaints ${ }^{(2)}$, and that $60 \%$ of its causes remain unknown following even conventional testing ${ }^{(1)}$, determining potentially related diseases and the best way to identify

${ }^{1}$ Gastroenterology Unit Dept. of Internal Medicine and ${ }^{2}$ Dept. of Pediatrics, Brasilia School of Medicine, University of Brasilia, DF, Brazil.

Address for correspondence: Dr. Vinícius Machado de Lima - SQSW 302, bloco D, apt. 405 - Setor Sudoeste - 70673-204 - Brasília, DF, Brazil. E-mail: viniciusbsb@brturbo.com 
them would have a substantial impact on clinical activities. Thus, the present study aimed at determining the prevalence of CD in dyspeptic patients attended at the Gastroenterology Outpatient Clinic of a general hospital and submitted to routine diagnostic endoscopy of the upper gastrointestinal tract.

\section{PATIENTS AND METHODS}

Patients with dyspeptic symptoms, attended at the outpatient Gastroenterology Clinic of the University Hospital of Brasilia, Brasilia, DF, Brazil, for diagnostic endoscopy of the upper gastrointestinal tract, were prospectively evaluated between October 2001 and October 2003. The study was approved by the Ethics Committee of the Medical School of the University of Brasilia. Patients received written and verbal information concerning the goals of the screening and provided their free and informed consent. Individuals were considered dyspeptic if they complained of persistent pain or discomfort in the upper abdomen. The study population included 34 men and 108 women, aged 14 years or more. Patients who were being tested for absorptive intestinal problems, who had chronic diarrhea, who were already known CD patients, or who had been previously diagnosed with digestive disorders that justified the dyspeptic complaints, were not included in the study.

Digestive endoscopies were carried out on a GIF-100 videoendoscope (Olympus Keymed, UK), and results recorded as normal or abnormal (esophagitis, ulcer, peptic duodenitis, cancer, possible celiac disease or others). Possible CD diagnosis was inferred by endoscopic markers of duodenal villous atrophy (i.e. scalloping of duodenal folds and mosaic mucosal pattern). Patients were submitted to gastric and second duodenal portion biopsies, and tissue samples underwent standard histological processing. Histological diagnosis of CD was based on the presence of intraepithelial lymphocytes, crypts hyperplasia and/or villi atrophy. Biopsy results were classified as absence of CD (O degree) or suggestive of CD (degrees I to IV), according to MARSH criteria ${ }^{(20)}$. Serological screening of CD was carried out on a blood sample obtained from each patient. Samples were centrifuged and the resulting sera stored at $-20^{\circ} \mathrm{C}$ until testing. The IgG-antigliadin (AGA) test was used as a first-level screening (QUANTA Lite Gliadin IgG ELISA, INOVA, USA). Optical density was reported in arbitrary units (U) as a percentage of the optical density of a pool of positive samples, being $20 \mathrm{U}$ the upper normal limit range (cut-off value), as determined by the manufacturer. All positive IgG-AGA sera underwent a second screening, being tested for the presence of IgA-antiendomysium (EMA) antibodies using an indirect immunofluorescence method (7) employing fixed cryostat sections of the distal portion of primate (Cebus apella) esophagus as antigen substrate. Fluorescein-labeled goat antibody to human $\operatorname{IgA}$ was used as second antibody. All sera were screened at a dilution of $1 / 5$. Under fluorescent microscope, the presence of a characteristic brilliant green network pattern was considered as positive. Serological data were correlated to the endoscopic results and to the histological pattern observed in the small intestine.
The prevalence, relative risk, and 95\% interval confidence were calculated by Fisher exact test using the EpiInfo $6^{\mathrm{Tm}}$.

\section{RESULTS}

A total of 142 dyspeptic patients took part in the study (108 women, 34 men; age range 14 and 75 years, median 47 years). Normal digestive endoscopies were observed in 29 (20\%) of the cases, 34 patients $(24 \%)$ demonstrated peptic esophagitis, 26 $(18 \%)$ had ulcers, $60(42 \%)$ with gastritis, $19(13 \%)$ had peptic-like duodenitis, $1(0.7 \%)$ with gastric cancer, and $16(11 \%)$ with other diagnoses. Helicobacter pylori was detected in 91 cases (64\%). In four patients $(2.8 \%)$ an endoscopic pattern suggestive of $\mathrm{CD}$ was observed. Twenty-four (17\%) of the 142 patients tested were IgG-AGA positive. IgA-EMA assays performed on all the IgG-AGA positive sera yielded two positive cases. Of the four patients with endoscopic pattern suggestive of CD, three tested positive for IgG-AGA. However, only in two patients was CD confirmed by IgA-EMA test and by the histological analysis of the intestinal biopsy samples (Table 1). Other intestinal diseases were diagnosed in the two non-celiac patients with endoscopic markers of villous atrophy. One of them, a patient with mosaic mucosal endoscopic pattern and inflammatory findings in duodenal biopsy specimen, had HIV enteropathy. In the second case, high serum antigliadin levels and cow's milk protein intolerance were observed. Abnormal endoscopic findings were notably marked in biopsy-proven CD patients (Figure 1). Therefore, a 1.4\% prevalence of $\mathrm{CD}$ was observed in this study group.

\begin{tabular}{|c|c|c|c|c|c|}
\hline Gender & Age & $\begin{array}{c}\text { AGA-IgG } \\
\text { (ELISA } \\
\text { units) }\end{array}$ & EMA & Histology & Enteropathy \\
\hline $\mathrm{F}$ & 40 & 14 & - & $\begin{array}{c}\text { IE; without } \\
\text { VA (Marsh } \\
0)\end{array}$ & $\begin{array}{c}\text { HIV } \\
\text { enteropathy }\end{array}$ \\
\hline $\mathrm{F}$ & 17 & 64 & - & $\begin{array}{c}\text { IE; without } \\
\text { VA (Marsh } \\
0)\end{array}$ & $\begin{array}{l}\text { Cow's milk } \\
\text { protein } \\
\text { intolerance }\end{array}$ \\
\hline $\mathrm{F}$ & 19 & 60 & + & $\begin{array}{c}\text { total VA } \\
\text { (Marsh IV) }\end{array}$ & $\begin{array}{l}\text { Celiac } \\
\text { disease }\end{array}$ \\
\hline F & 25 & 115 & + & $\begin{array}{c}\text { subtotal VA } \\
\text { (Marsh III) }\end{array}$ & $\begin{array}{l}\text { Celiac } \\
\text { disease }\end{array}$ \\
\hline
\end{tabular}

$\mathrm{F}=$ female; $\mathrm{IE}$ = inflammatory enteropathy; $\mathrm{VA}$ = villous atrophy

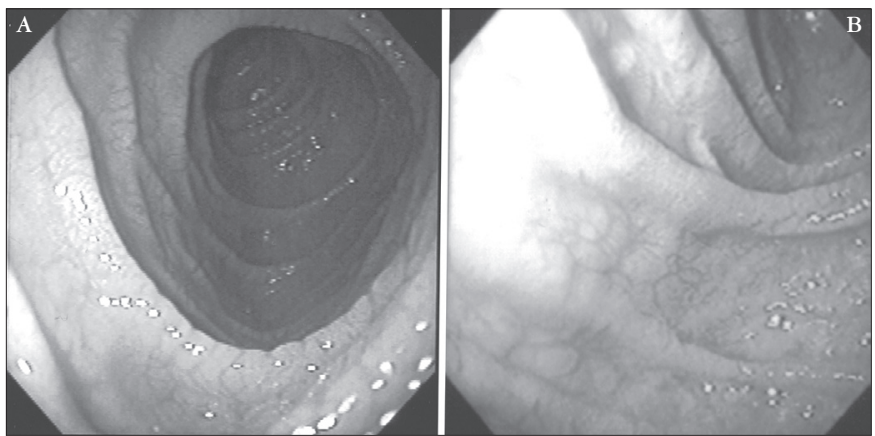

FIGURE 1 - Endoscopic view of duodenum in celiacs patients showing a scalloping of folds (A) and mosaic pattern (B) 


\section{DISCUSSION}

In the present study, the high prevalence of celiacs among dyspeptic symptomatic individuals indicates this sub-group of patients as being at a higher risk for developing CD. Compared to previous serological assessment of CD prevalence, this result was significantly greater. In a recent study, our group tested a presumably healthy population of blood donors in the same region and found a prevalence of undiagnosed CD of $1: 681^{(15)}$. The prevalence in dyspeptic patients was 9.6 fold higher than that of these donors (relative risk: 9.6; 95\% confidence interval, $1.62-57, P=0.03)$. Similar findings have been previously reported, in that the occurrence of CD was found to be twice as high as that observed in the general Italian population ${ }^{(3)}$. Furthermore, during the evaluation of a group of dyspeptic patients, VIVAS et al. ${ }^{(30)}$ identified approximately $3 \%$ of celiacs, while only $0.6 \%$ of the control group was diagnosed as gluten-intolerant.

In addition to serological tests, digestive endoscopy has also been employed to detect celiacs among dyspeptic individuals, given that this procedure is normally carried out during routine diagnostic check-ups. Endoscopic markers of duodenal villous atrophy, with mosaic pattern and scalloping of folds, have been suggested as characteristic features of $\mathrm{CD}^{(12)}$ (Figure 1). Applying this method DICKEY ${ }^{(11)}$ observed a $1.6 \%$ prevalence of CD among individuals submitted to endoscopies due to digestive complaints. In fact, evaluation of endoscopic results in a large number of patients during standard examinations demonstrated these indicators as being disappointingly insensitive, with markers present in only $58 \%$ of those with partial mucosa atrophy ${ }^{(13)}$. Consequently, endoscopic changes may be insufficient in detecting $\mathrm{CD}$, particularly in less severe cases, sub-estimating the real prevalence of this disorder. In the present study, these markers were unspecific. Only two out of four patients presenting endoscopic features considered as suggestive of CD were truly diagnosed as celiacs. Furthermore, a patient with HIV enteropathy and a mosaic endoscopic pattern was identified. Similar cases have been reported in the medical literature. The endoscopic markers may be present in infectious or inflammatory conditions of the small bowel as HIVassociated opportunistic infections, HIV enteropathy, tropical sprue, giardiasis and eosinophilic enteritis ${ }^{(26)}$. For a differential diagnosis, another factor to consider includes cow's milk protein intolerance. In fact, one of the non-celiac patients with positive endoscopic markers demonstrated this condition. This type of intolerance may lead to an inflammatory enteropathy and high serum antigliadin levels. In this disease, the presence of protein-directed antibodies could be explained by the increased permeability of the macromolecules in scattered areas of the damaged mucosa. Such change may possibly increase gliadin permeability across the mucosal barrier, thus stimulating the immune system ${ }^{(4)}$. Indeed endoscopic markers can be seen in a variety of other diseases, of which CD is one of the most common causes. Different studies have demonstrated that these endoscopic findings have a 95\%-100\% specificity for villous atrophy ${ }^{(22,27)}$.Therefore, scalloping, decreased number of duodenal folds, and a mosaic-like mucosal pattern should be considered markers of mucosal pathology. Hence, the recognition of these markers must prompt endoscopists to obtain biopsies to confirm the presence of mucosal disease. This procedure may facilitate the detection of readily treatable conditions, such as unsuspected celiac disease.

In view of the unsatisfactory sensitivity of endoscopic markers, carrying out routine duodenal biopsy in all dyspeptic patients submitted to endoscopy is thought to increase probability of CD diagnosis in some European centers ${ }^{(17)}$. Such procedure is debatable, however, due to its additional costs. Serology, even when employing tests of low positive-predictive value in populations with a low CD prevalence, is an excellent screening tool, restricting the number of individuals that may have to be subsequently submitted to biopsies. This diagnostic method can also be advantageous in groups who are at a higher risk than the general population, as is the case of dyspeptic patients. Serological tests can help circumvent the low-sensitivity issue of endoscopic markers. Should a negative serologic result be obtained, small bowel biopsies would then be unnecessary in patients with a normal endoscopic duodenal mucosa. The dyspeptic patients investigated in this study were initially screened with the IgG-AGA antibody test, a low-cost highly available and sensitive serological assay, albeit not as specific as the IgA-AGA assay ${ }^{(18)}$. As a corroborative procedure, an IgA-EMA assay was also conducted due to its high specificity $(99 \%)^{(29)}$. The consensus observed between EMA and histopathological changes demonstrates the accuracy of this test and further corroborates the notion that endoscopic biopsies during daily clinical activities may be limited to positive-serology cases and/or patients with endoscopic markers of villous atrophy.

The consequences of undiagnosed $\mathrm{CD}$ can be serious. This disorder has been associated with a high morbidity and elevated mortality rate, compared to the general population ${ }^{(10)}$. Gluten-free diet has been shown to reverse this scenario, even reducing the tendency to develop CD-associated malignant neoplasias ${ }^{(9)}$, further indicating the importance of early diagnosis of this disorder.

In view of the consequences of untreated $\mathrm{CD}$, the large contingency of dyspeptics without proper diagnosis, and the high prevalence of this disease among these patients, it is particularly important for endoscopists to be attentive for presence of endoscopic evidences of villous atrophy, thus possibly identifying unsuspected CD. Furthermore, the inclusion of serological CD assays in routine testing for dyspepsia should be strongly recommended. This approach would allow the identification of negative endoscopic CD markers, as well as provide reasonable indications for a duodenal biopsy. 
Lima VM, Gandolfi L, Pires JAA, Pratesi R. Prevalência de doença celíaca em pacientes dispépticos. Arq Gastroenterol 2005;42(3):153-6.

RESUMO - Racional - A doença celíaca, uma das mais comuns enteropatias inflamatórias mediadas por um componente da dieta, ocorre em resposta à intolerância ao glúten nos indivíduos geneticamente predispostos. Com a disponibilidade dos exames sorológicos, essa enfermidade tem se mostrado mais freqüente que no passado, contudo seu diagnóstico ainda é, habitualmente, tardio. A pesquisa de intolerância ao glúten em pacientes com sintomas dispépticos, possível manifestação clínica da doença celíaca, pode permitir uma detecção mais precoce dos indivíduos afetados. Objetivo - Determinar a prevalência de doença celíaca em pacientes dispépticos submetidos a endoscopia digestiva alta de rotina. Pacientes/Métodos - Achados endoscópicos, análise histológica da mucosa duodenal e resultado de testes sorológicos de 142 pacientes consecutivos com dispepsia foram obtidos entre outubro de 2001 e outubro de 2003, e comparados. Resultados - O padrão endoscópico sugestivo de doença celíaca foi encontrado em quatro pacientes. O teste IgG-AGA foi positivo em 24 pacientes. Dois dos pacientes IgG-AGA positivos também apresentaram teste IgA-EMA positivo e padrão endoscópico e histológico duodenal compatíveis com doença celíaca. Alterações endoscópicas duodenais foram expressivamente mais evidentes nestes pacientes. A prevalência de doença celíaca observada neste estudo foi de 1,4\%. Conclusão - Pacientes dispépticos, por sua elevada prevalência de doença celíaca, são um grupo de maior risco para essa patologia. Celíacos sem diagnóstico prévio podem ser identificados através de marcadores endoscópicos de atrofia vilositária duodenal. Entretanto, essas alterações endoscópicas podem ser insuficientes para que o diagnóstico seja estabelecido e, conseqüentemente, deve ser recomendada a inclusão de testes sorológicos para doença celíaca na investigação dos pacientes com dispepsia.

DESCRITORES - Doença celíaca. Dispepsia. Prevalência.

\section{REFERENCES}

1. American Gastroenterological Association. Medical position statement: evaluation of dyspepsia. Gastroenterology 1998;114:579-81.

2. Axon A. Management of uninvestigated dyspepsia: review and commentary. Gut 2002;50:51-7.

3. Bardella MT, Minoli G, Ravizza D, Radaelli F, Vielo P, Quatrini M, Bianchi PA, Conte D. Increased prevalence of celiac disease in patients with dyspepsia. Arch Intern Med 2000;160:1489-1491.

4. Bottaro G. The predictive value of antigliadin antibodies (AGA) in the diagnosis of non-celiac gastrointestinal disease in children. Minerva Pediatr 1993;45:93-8.

5. Catassi C, Rätsch IM, Fabiani E, Rossini M, Bordicchia F, Candela F, Coppa GV, Giorgi PL. Celiac disease in the year 2000: exploring the iceberg. Lancet 1994;343:200-3.

6. Catassi C, Fabiani E, Rästch IM, Coppa GV, Giorgi PL, Pierdomenico R, Alessandri S, Iwannejko G, Domenici R, Mei E, Miano A, Marani M, Bottaro G, Spina M, Dotti M, Montanelli A, BarbatoM, Viola F, Lazzari R, Vallini M, Guariso G, Plebani M, Cataldo F, Traverso G, Ventura A. The coeliac iceberg in Italy. A multicentre antigliadin antibodies screening for coeliac disease in school-age subjects. Acta Paediatr Suppl 1996; 412:29-35.

7. Chorzelski TP, Beutner EH, Sulej J, Chorzewska H, Jablonska S, Kumar V, Kapuscinska A. IgA antiendomysium-antibody. A new immunological marker of dermatitis herpetiformis and coeliac disease. Br J Dermatol 1986;87:703-6.

8. Ciclitira PJ. AGA technical review on celiac sprue. American Gastroenterological Association practice guidelines. Gastroenterology 2001;120:1526-40.

9. Collin P, Reunala T, Pukkala E, Laippala P, Keyrilainen O, Pasternack A. Coeliac disease-associated disorders and survival. Gut 1994;35:1215-8.

10. Cottone M, Termini A, Oliva L, Magliocco A, Marrone C, Orlando A, Pinzone F, Di Mitri R, Rosselli M, Rizzo A, Pagliaro L. Mortality and causes of death in celiac disease in a Mediterranean area. Dig Dis Sci 1999;44:2538-41.

11. Dickey W. Diagnosis of coeliac disease at open acess endoscopy. Scand J Gastroenterol 1998;33:612-5

12. Dickey W, Hughes D. Prevalence of celiac disease and its endoscopic markers among patients having routine upper gastrointestinal endoscopy. Am J Gastroenterol 1999;94:2182-6.

13. Dickey W, Hughes D. Disappointing sensitivity of endoscopic markers for villous atrophy in a high-risk population: implications for celiac disease diagnosis during routine endoscopy. Am J Gastroenterol 2001;96:2126-8.

14. Feighery C. Celiac disease. Br Med J 1999;319:236-9.

15. Gandolfi L, Pratesi R, Cordoba JC, Tauil PL, Gasparin M, Catassi C. Prevalence of celiac disease among blood donors in Brazil. Am J Gastroenterol 2000;95:689-92.

16. Gomez JC, Selvaggio GS, Viola M, Pizarro B, La Motta G, Barrio S, Castelletto R, Echeverría $\mathrm{R}$, Sugai E, Vazquez H, Mauriño E, Bai JC. Prevalence of celiac disease in Argentina: screening of an adult population in the La Plata area. Am J Gastroenterol 2001;96:2700-4.
17. Green PHR, Fleischauer AT, Bhagat G, Goyal R, Jabri B, Neugu AI. Risk of malignancy in patients with celiac disease. Am J Med 2003;115:191-5.

18. Guandalini S, Gupta P. Celiac disease - a diagnostic challenge with many facets. Clin Applied Immunol Rev 2002;2:293-305.

19. Ivarsson A, Person LA, Juto P. High prevalence of undiagnosed celiac disease in adults: a Swedish population-based study. J Intern Med 1999;245:63-8.

20. Marsh MN. Gluten, major histocompatibility complex, and the small intestine Gastroenterology 1992;102:330-54

21. Midhagen G, Jarnerot G, Kraaz W. Adult celiac disease within a defined geographical area in Sweden. A study of prevalence and associated diseases. Scand J Gastroenterol 1988;23:1000-4.

22. Niveloni S, Fiorini A, Dezi R, Pedreira S, Smecuol E, Vasquez H. Usefulness of videoduodenoscopy and vital dye staining as indicators of mucosal atrophy of celiac disease: assesment of interobserver agreement. Gastrointest Endosc 1998;47:223-9.

23. Not T, Horvath K, Hill ID, Partanen J, Hammed A, Magazzu Fasano A. Celiac disease risk in the USA: high prevalence of antiendomysium antibodies in healthy blood donors. Scand J Gastroenterol 1998;33:494-8.

24. Papadopoulus JK, Wijmenga C, Koning F. Interplay between genetics and the environment in the development of celiac disease: perspectives of a healthy life. J Clin Invest 2001;108:1261-6.

25. Pratesi R, Gandolfi L, Garcia SG, Modelli IC, Almeida PL, Bocca AL, Catassi C. Prevalence of coeliac disease: unexplained aged-related variation in the same population. Scand J Gastroenterol 2003;38:747-50.

26. Shah VH, Rotterdam H, Kotler DP, Fasano A, Green PHR. All that scallops is not celiac disease. Gastrointest Endosc 2000;51:717-20.

27. Smith AD, Graham I, Rose JDR. A prospective endoscopic study of scalloped folds and grooves in the mucosa of the duodenum as signs of villous atrophy. Gastrointes Endosc 1998;47:461-5.

28. Sollid LM. Molecular basis of celiac disease. Annu Rev Immunol 2000;18:53-81.

29. Stern M, Working Group on Serologic Screening for Celiac Disease. Comparative evaluation of serologic tests for celiac disease: an European initiative toward standardization. J Pediatr Gastroenterol Nutr 2000;31:513-9.

30. Vivas S, Ruiz de Morales JM, Martinez J, Gonzalez MC, Martin S, Martin J, Cechini $\mathrm{C}, \mathrm{Olcoz} \mathrm{JL}$. Human recombinant antitransglutaminase antibody testing is useful in the diagnosis of silent coeliac disease in a selected group of at-risk patients. Eur J Gastroenterol Hepatol 2003;15:479-83. 